\title{
Хірургічне лікування хронічної ішемії, що загрожуе втраті нижньої кінцівки, у хворих із оклюзивно-стенотичним ураженням гомілкових артеріӥ
}

\begin{abstract}
Мета роботи: покращити результати хірургічного лікування хронічної ішемії, що загрожує втраті нижньої кінцівки, в умовах оклюзивно-стенотичного процесу гомілкових артерій.

Матеріали і методи. Реваскуляризуючі операційні втручання на інфраінгвінальному артеріальному руслі при стенотичнооклюзивному ураженні гомілкових артерій проведено у 95 пацієнтів. 3 метою встановлення характеру та поширеності оклюзивно-стенотичного ураження інфраінгвінального артеріального русла застосовували дуплексне ультразвукове сканування та комп’ютерну томографію із контрастуванням судинного русла.

Результати досліджень та їх обговорення. Основною причиною припинення функціонування анастомозу у віддаленому післяопераційному періоді був тромбоз, який діагностовано у 9 (9,68 \%) пацієнтів. Найчастіше (3 випадки) його виявляли в період 4-5 місяців віддаленого післяопераційного періоду. В кінці другого місяця спостерігали один випадок тромбозу сегмента реконструкції. На межі 9 і 10 місяців післяопераційного періоду виявили два випадки тромбозу, а в період між 19 і 33 місяцем віддаленого післяопераційного періоду діагностовано 3 прояви тромбозу сегмента реконструкції.

Аналіз хірургічного лікування хронічної ішемії, що загрожує втраті нижньої кінцівки, у хворих із оклюзивно-стенотичним ураженням гомілкових артерій встановив, що при 36 місячному поопераційному спостереженні кумулятивна прохідність збережених кінцівок склала 92,63 \%, прохідність реконструкції - 73,57 \%. Подібне вдалось досягнути за рахунок диференційованого підходу до вибору локації дистального анастомозу автовенозного шунта (дистальний, проксимальний сегмент гомілкових артерій) і включення у кровотік стопних артерій та у більшості формування дистального анастомозу за типом “кінець у кінець”.
\end{abstract}

Ключові слова: хронічна ішемія; атеросклероз; інфраінгвінальний сегмент; реваскуляризація; тромбоз; шунт; анастомоз.

Постановка проблеми і аналіз останніх досліджень та публікацій. У структурі серцево-судинних захворювань оклюзивно-стенотичні ураження артерій нижніх кінцівок займають друге місце і поступаються тільки ішемічній хворобі серця [1]. Більш ніж у 55 \% пацієнтів виявляють атеросклеротичне ураження стегно-дистальних артеріальних сегментів [2]. Оклюзивно-стенотичні ураження інфраінгвінального артеріального русла у 35-65 \% спостережень призводять до розвитку хронічної критичної ішемії [3]. Хірургічне лікування хворих із інфраінгвінальним атеросклеротичним ураженням артеріального русла в ряді спостережень становить складне завдання [4]. Складність оперативних втручань на стегнодистальній артеріальній зоні зумовлена багаторівневим атеросклеротичним ураженням артеріального русла, поширенням ураження на прилеглі артеріальні басейни, колатеральні артеріальні басейни та станом шляхів відтоку - гомілкових артерій (ГА) [5]. Водночас реваскуляризуючі хірургічні втручання на стегново-дистальному артеріальному руслі i, особливо, на гомілкових артеріях при хронічній критичній ішемії залишаються єдиним шансом уникнути ампутації нижньої кінцівки [6]. Тому триває пошук і апробація оптимальних методів реваскуляризуючих оперативних втручань на інфраінгвінальному артеріальному руслі в умовах стенотично-оклюзивного ураження артерій гомілки.

Мета роботи: покращити результати хірургічного лікування хронічної ішемії, що загрожує втраті нижньої кінцівки, в умовах оклюзивно-стенотичного процесу гомілкових артерій.

Матеріали і методи. Реваскуляризуючі оперативні втручання на інфраінгвінальному артеріальному руслі при стенотично-оклюзивному ураженні гомілкових артерій проведено у 95 пацієнтів. Згідно з Міжнародними судинними рекомендаціями лікування хронічної ішемії, що загрожує втраті кінцівки, клінічні стадії визначали за класифікацією WIFI (2019). При цьому у 11 (11,58 \%) пацієнтів встановлено 2 клінічну стадію, у 56 (58,95 \%) - 3 клінічну стадію, у 31 (32,63 \%) - 4 клінічну стадію.

На доопераційному етапі 95 пацієнтам з метою встановлення характеру та поширеності стенотично-оклюзивного ураження інфраінгвінального артеріального русла застосовували дуплексне ультразвукове сканування та комп’ютерну томографію із контрастуванням судинного русла. 
При обстеженні встановлено багатоповерховість атеросклеротичного ураження інфраінгвінального артеріального русла нижніх кінцівок. Крім стенотично-оклюзивного процесу гомілкових артерій (95 спостережень), стенотично-оклюзивний процес було виявлено у 21 (22,11 \%) випадку на рівні загальної артерії стегна (ЗАС), у 40 (42,11 \%) - на рівні поверхневої артерії стегна (ПАС), у 9 (9,48 \%) - на рівні підколінної артеpiї (ПА). У 25 (26,32 \%) спостереженнях встановлено поєднання стенотично-оклюзивного процесу двох артеріальних сегментів: у 23 (24,21 \%) - поширення процесу із загальної артерії стегна на поверхневу артерію стегна, у 2 (2,11 \%) - поширення процесу із поверхневої артерії стегна на підколінну артерію.

При ультразвуковому дуплексному скануванні у 29 (30,53 \%) спостереженнях встановлено стеноз в межах 53-71 \% гирла (I порція) глибокої артерії стегна (ГАС). Потрібно зазначити, що стенозуючий процес гирла ГАС виявлено у випадках локалізації стенотично-оклюзивного процесу на рівні ЗАС і при поширенні стенотично-оклюзивного процесу із ЗАС на ПСА.

Результати досліджень та їх обговорення. Хірургічне лікування пацієнтів із стенотичнооклюзивним процесом стегно-дистального артеріального русла у поєднанні із стенотично-оклюзивним ураженням гомілкових артерій розпочинали із виділення стегнових артерій, ПА і ГА в типових для них доступах.

У майже половині спостережень дистальний анастомоз шунта формували із задньою великогомілковою артерією (ЗВГА), при чому у 14 випадках - на рівні її проксимального сегмента, а у 28 - на рівні дистального. У 23 пацієнтів дистальний анастомоз шунта формували із передньою великогомілковою артерією (ПВГА), у 15 випадках - на рівні ії̈ проксимального сегмента, а у 8 - на рівні дистального. В 16 спостереженнях дистальний анастомоз шунта формували на рівні тібіоперонеального стовбура (ТПС), у 8 - із малогомілковою артерією (МГА), у 6 пацієнтів провели стопне шунтування (у 4 - заднє стопне шунтування, у 2 переднє стопне шунтування).

42 (44,21 \%) випадки формування дистального анастомозу припадає на анастомози, сформовані на рівні дистальних сегментів гомілкових і стопних артерій. У 25 (59,52 \%) з них анастомози сформовані за типом “кінець у кінець.“

3 (55,79 \%) випадки формування дистального анастомозу припадає на анастомози, сформовані на рівні проксимальних сегментів гомілкових ар- терій та ТПС і МГА. В 36 (67,92 \%) із них анастомози сформовані за типом “кінець у кінець.“

Після формування дистального анастомозу автовенозного шунта здійснювали його проведення анатомічно через канал вздовж судинно-нервового пучка або екстраанатомічно на стегні по латеральній поверхні або на гомілці під фасцією. При шунтуванні використовували автовену (ВПВ, МПВ), вени верхньої кінцівки. Після наведеної маніпуляції формували проксимальний анастомоз автовенозного шунта за типом "кінець у бік“ або “кінець у кінець“ із обраною стегновою артерією.

Проксимальний анастомоз автовенозного шунта у 21 (22,11 \%) спостереженні формували на ріні 3АС, у 23 (24,21 \%) - на рівні ЗАС в умовах поширення процесу на ПАС. У більшій частині наведеного рівня формування проксимального анастомозу (29 (65,91 \%) спостережень) формуванню проксимального анастомозу передувало проведення профундопластики.

У 40 (42,11 \%) спостереженнях проксимальний анастомоз формували на рівні ПАС: у 18 (45,0 \%) випадках - у її проксимальному сегменті і у 22 (55,0 \%) - у дистальному сегменті ПАС. У 11 (11,58 \%) хворих проксимальний анастомоз формували на рівні підколінної артерії; у 7 спостереженнях - на рівні вище колінної щілини, а у 4 випадках - нижче колінної щілини.

Проксимальний анастомоз на рівні ПА в 11 (11,58 \%) спостереженнях виконано при проведенні реконструктивних операцій на артеріях стопи. Позиціонували шунти екстраанатомічно у нижній третині гомілки. Виконано 6 підколінно-стопних шунтувань, серед яких у 4 випадках із задньою стопною артерією, а у 2 - із передньою стопною артерією.

Безпосередні результати хірургічного лікування 95 хворих із стенотично-оклюзивним процесом інфраінгвінального артеріального русла при стенотично-оклюзивному ураженні артерій гомілки оцінювали згідно з показниками реваскуляризації впродовж 30 діб після оперативного втручання. Впродовж вказаного періоду спостерігали розвиток тромбозу сегмента реконструкції у 3 (3,16 \%) пацієнтів. Решунтування одночасно із тромбектомією проведено в одного пацієнта, у двох інших - тромбектомію із реконструкцією дистального анастомозу. Слід вказати, що тромбоз розвинувся на рівні дистальних анастомозів, які були сформовані на рівні проксимальних сегментів гомілкових артерій за типом “кінець у бік”.

У 2 пацієнтів після реваскуляризації нижньої кінцівки спостерігали збереження і прогресування ішемії нижніх кінцівок. У пацієнтів були відсут- 
ні умови до повторного оперативного втручання. Інтенсивна консервативна терапія не дала можливості компенсувати прогресуючу ішемію, що призвело до виконання ампутації нижньої кінцівки.

Прослідковано впродовж 36 місяців післяопераційного періоду результати хірургічного лікування стенотично-оклюзивного процесу інфраінгвінального артеріального русла у 93 пацієнтів. Встановлено, що залежно від локалізації анастомозів автовенозного шунта (дистальний, проксимальний) існує різниця у тривалості періоду збереження і функціонування. Так, тривалість періоду збереження і функціонування проксимальних анастомозів була в межах, відповідно, $(23,92 \pm 1,71)$ i $(21,51 \pm 5,1)$ місяця, а тривалість періоду збереження і функціонування дистальних анастомозів складає $(16,96 \pm 3,44)$ і $(14,46 \pm 2,62)$ місяця відповідно. При цьому тривалість періоду збереження і функціонування проксимальних анастомозів в 1,4 раза (p < 0,05) довша від тривалості періоду збереження і функціонування дистальних анастомозів (табл. 1).

Основною причиною припинення функціонування анастомозу у віддаленому післяоперацій- ному періоді був тромбоз, який діагностовано у 9 (9,68 \%) пацієнтів. Найчастіше (3 випадки) його виявляли в період 4-5 місяців віддаленого післяопераційного періоду. У кінці другого місяця спостерігали один випадок тромбозу сегмента реконструкції. На межі 9 і 10 місяців післяопераційного періоду виявили два випадки тромбозу, а в період між 19 і 33 місяцем віддаленого післяопераційного періоду діагностовано 3 прояви тромбозу сегмента реконструкції.

Оперативне лікуванню тромбозу сегмента реконструкції у віддаленому періоді реваскуляризації інфраінгінального артеріального русла виконано 9 пацієнтам. Решунтування здійснено у 3 хворих: у одного - одночасно із тромбектомією, у двох інших - тромбектомію доповнили формуванням фістули. Тромбектомію із реконструкцією анастомозів проведено у 6 пацієнтів: у 5 спостереженнях - реконструкція дистального анастомозу і тільки в одного - проксимального анастомозу.

П’ять пацієнтів госпіталізовано на 7-12 доби після розвитку тромбозу сегмента реконструкції. У них було діагностовано хронічну ішемію, що загрожує втраті кінцівки, 4 клінічна стадія (за кла-

Таблиця 1. Період збереження та період функціонування анастомозів стегно-дистального автовенозного шунта

\begin{tabular}{|c|c|c|c|c|c|}
\hline \multirow{2}{*}{$\begin{array}{l}\text { Локалізація } \\
\text { анастомозу }\end{array}$} & \multirow{2}{*}{$\begin{array}{l}\text { Абсолютна } \\
\text { кількість }\end{array}$} & \multicolumn{2}{|c|}{ Період збереження } & \multicolumn{2}{|c|}{ Період функціонування } \\
\hline & & M & $\pm \mathrm{m}$ & M & $\pm \mathrm{m}$ \\
\hline $\begin{array}{l}\text { Проксимальний анастомоз } \\
\text { на рівні ЗАС } \\
\text { ЗАС пош. ПАС } \\
\text { ПАС п/с }\end{array}$ & 59 & 25,06 & 1,23 & 21,62 & 1,22 \\
\hline $\begin{array}{l}\text { Проксимальний анастомоз } \\
\text { ПАС д/с } \\
\text { ПкА в/к }\end{array}$ & 28 & 24,17 & 1,41 & 22,59 & 1,73 \\
\hline $\begin{array}{l}\text { Проксимальний анастомоз } \\
\text { ПкА н/к }\end{array}$ & 7 & 22,52 & 2,49 & 20,32 & 2,43 \\
\hline $\begin{array}{l}\text { Дистальний анастомоз } \\
\text { ЗВГА п/с } \\
\text { ПВГА п/с } \\
\text { ТПС }\end{array}$ & 41 & 20,15 & 1,43 & 18,94 & 1,27 \\
\hline $\begin{array}{l}\text { Дистальний анастомоз } \\
\text { ЗВГА д/с } \\
\text { ПВГА д/с } \\
\text { МГА }\end{array}$ & 40 & 17,36 & 1,32 & 13,17 & 1,33 \\
\hline $\begin{array}{l}\text { Дистальний анастомоз } \\
\text { стоп. задн. } \\
\text { стоп. перед. }\end{array}$ & 6 & 13,43 & 4,13 & 11,34 & 4,87 \\
\hline
\end{tabular}


сифікацією WIFI (2019)). У всіх пацієнтів зусилля інтенсивної консервативної терапії та спроби відновити кровотік не мали успіху, що призвело до ампутації нижньої кінцівки.

Реконструктивні втручання інфраінгвінального артеріального русла із одночасною реваскуляризацією гомілкових артерій залишаються єдиною можливістю уникнути ампутації нижньої кінцівки [7]. Проте багатоповерховість атеросклеротичного ураження судинного русла нижньої кінцівки в ряді спостережень створює перешкоду для виконання дистальної реконструкції [8]. Останнє спонукає до пошуку та вдосконалення методів реваскуляризації артерій гомілкового сегмента [9, 10].

95 пацієнтам проведено реваскуляризацію інфраінгвінального судинного русла із одномоментним відновленням кровотоку в гомілкових артеріях. Формували дистальний анастомоз відповідно до поширення оклюзивного процесу у гомілкових артеріях. 42 (44,21 \%) випадки дистального анастомозу припадає на анастомози, що сформовані на рівні дистальних сегментів гомілкових і стопних артерій. У 53 (55,79 \%) спостереженнях дистальний анастомоз сформовано на рівні проксимальних сегментів гомілкових артерій та ТПС і МГА. У 61 (64,21 \%) спостереженні анастомоз автовени із гомілковою артерією формувався за типом “кінець у кінець”.

При ультразвуковому дуплексному скануванні у 29 (30,53 \%) спостереженнях встановлено стеноз у межах 53-71 \% гирла (I порція) ГАС. Проксимальний анастомоз автовенозного шунта у 21 (22,11 \%) спостереженні формували на рівні ЗАС, у $23(24,21 \%)$ - на рівні ЗАС в умовах поширення процесу на ПАС. У більшій частині наведеного рівня формуванню проксимального анастомозу (29 (65,91 \%) спостережень) передувало проведення профундопластики.

У 40 (42,11 \%) спостереженнях проксимальний анастомоз формували на рівні ПАС: у 18 (45,0 \%) випадках - у її проксимальному сегменті і у 22 (55,0 \%) - в дистальному сегменті ПАС. У 11 (11,58 \%) хворих проксимальний анастомоз формували на рівні підколінної артерії: у 7 спостереженнях - на рівні вище колінної щілини ПА, а у 4 випадках - нижче колінної щілини ПА.

Необхідність повторної реконструкції після реваскуляризації стегно-дистального відновлення кровотоку виникає майже у 30 \% оперованих хворих. До цього призводять розвиток післяопераційного тромбозу та рестенози, частота яких коливається в межах від 6 до 42 \% [11, 12].

Впродовж раннього післяопераційного періоду діагностували розвиток тромбозу сегмента ре- конструкції у 3 (3,16 \%) пацієнтів. Решунтування одночасно із тромбектомією проведено в одного пацієнта, у двох інших - тромбектомію із реконструкцією дистального анастомозу.

Основною причиною припинення фунціонування анастомозу у віддаленому післяопераційному періоді був тромбоз, який діагностовано у 9 $(9,68$ \%) пацієнтів. Найчастіше, 3 випадки, його виявлено в період 4-5 місяців віддаленого післяопераційного періоду, в кінці другого місяця - один випадок тромбозу, на межі 9 і 10 місяців післяопераційного періоду - 2 випадки тромбозу, а в період між 19 і 33 місяцями віддаленого поопераційного періоду - 3 випадки тромбозу. Решунтування здійснено у 3 хворих: в одного - одночасно із тромбектомією, у двох інших - тромбектомію доповнили формуванням фістули. Тромбектомію із реконструкцією анастомозів проведено у 6 пацієнтів: в 5 спостереженнях - реконструкція дистального анастомозу і тільки в одного - проксимального анастомозу.

5 пацієнтів госпіталізовано на 7-12 доби після розвитку тромбозу сегмента реконструкції. У них було діагностовано хронічну ішемію, що загрожує втраті кінцівки, 4 клінічна стадія (за класифікацією WIFI (2019)). Зусилля інтенсивної консервативної терапії та спроби відновити кровотік у пацієнтів не мали успіху, що призвело до проведення ампутації нижньої кінцівки.

Провівши аналіз хірургічного лікування хронічної ішемії, що загрожує втраті нижньої кінцівки, у хворих із оклюзивно-стенотичним ураженням гомілкових артерій, встановлено, що при 36 місячному поопераційному спостереженні кумулятивна прохідність збережених кінцівок склала 92,63 \%, прохідність реконструкції - 73,57 \%. Подібне вдалось досягнути за рахунок диференційованого підходу до вибору локації дистального анастомозу автовенозного шунта (дистальний, проксимальний сегмент гомілкових артерій) і включення у кровотік стопних артерій та у більшості формування дистального анастомозу за типом “кінець у кінець”.

Висновок. Диференційний вибір місця формування дистального анастомозу автовенозного шунта, яке визначається поширенням атеросклеротичного процесу в гомілкових артеріях (дистальний, проксимальний сегмент), відновлення кровотоку через стопні артерії значно знижує частоту розвитку тромбозу сегмента реконструкції і тим самим дає можливість при 36 місячному післяопераційному спостереженні досягти 92,63 \% кумулятивної прохідності збережених кінцівок і 73,57 \% прохідності реконструкції артеріального русла. 


\section{З ДОСВІДУ РОБОТИ}

\section{СПИСОК ЛІТЕРАТУРИ}

1. Rollins K. E. Meta-analisis of contemporary shot- and longterm mortality rates in patients diagnosedwith critical leg ischatmia / K. E. Rollins, D. Jackson, P. A. Coughlin // Br. J. Surg. - 2013. Vol. 100 (8). - P. 1002-1008.

2. Neville R. F. An expanded seies of distal bypass using the distal vein patch technigue to improve prosthetic graft perforvance in critical limb ischemia / R. F. Neville, M. Lidsky, A. Capone // Eur. J. Vasc. Endovasc. Surg. - 2012. - Vol. 44 (2). - P. 177-182. 3. Raju R. Composite suguential bypass using profunda vein hitchhike / R. Raju, K. Mathur, M. K. Ayyappan // J. Vasc. Surg. - 2016. - Vol. 64 (2). - P. 526-529.

4. Prior failed ipsilatedal percutaneous endovascular intervention in patiens with critical limb ischemia predicts poor outcome after lower extremity bypass / B. W. Nolan, R. R. De Martino, D. H. Stone [et al.] // J. Vasc. Surg. - 2011. - Vol. 54 (3). - P. 730-735.

5. Реконструктивні операції на артеріях стопи в лікуванні критичної ішемії нижніх кінцівок / I. І. Кобза, Я. І. Ярема, Р. А. Жук, Д. Є. Федорів // Серце і судини. - 2018. - № 1 (61). - С. 37-39.

6. Гудз I. М. Роль та місце артеріо-венозної нориці в реконструкціях артерій нижніх кінцівок / І. М. Гудз, О. І. Гудз // Серце і судини. - 2010. - № 1. - С. 93-96.

7. Comparative study of venous arterialization and pedal bypass in a

\section{REFERENCES}

1. Rollins, K., Jackson, D., \& Coughlin, P. (2013). Meta-analysis of contemporary short- and long-term mortality rates in patients diagnosed with critical leg ischaemia. Br. J. Surg., 100 (8), 1002-1008. DOI: 10.1002/bjs.9127.

2. Neville, R., Lidsky, M., Capone, A., Babrowicz, J., Rahbar, R., \& Sidawy, A. (2012). An expanded series of distal bypass using the distal vein patch technique to improve prosthetic graft performance in critical limb ischemia. Eur. J. Vasc. Endovasc. Surg., 44 (2), 177-182. DOI: 10.1016/j.ejvs.2012.04.014.

3. Raju, R., Mathur, K., Ayyappan, M., Vijayakumar, J., Venkatesan, V., \& Venkatachalapathy, B. (2016). Composite sequential bypass using profunda vein hitchhike. J. Vasc. Surg., 64 (2), 526-529. DOI: 10.1016/j.jvs.2016.04.050.

4. Nolan, B., De Martino, R., Stone, D., Schanzer, A., Goodney, P., Walsh, D., \& Cronenwett, J. (2011). Prior failed ipsilateral percutaneous endovascular intervention in patients with critical limb ischemia predicts poor outcome after lower extremity bypass. J. Vasc. Surg., 54 (3), 730-735. DOI: 10.1016/j.jvs.2011.03.236.

5. Kobza, I.I., Yarema, Y.I., Zhuk, R.A., \& Fedoriv, D. Ye. (2018). Rekonstruktyvni operatsii na arteriiakh stopy v likuvanni krytychnoi ishemii nyzhnikh kintsivok [Reconstructive surgery on the arteries of the foot in treatment critical ischemia of the lower extremities]. Sertse i sudyny - Heart and Vessels, 1 (61), 37-39 [in Ukrainian].

6. Hudz, I.M., \& Hudz, O.I. (2010). Rol ta mistse arterio-venoznii norytsi v rekonstruktsiiakh arterii nyzhnikh kintsivok [The role and place of arterio-venous fistula in the reconstruction of the arteries of the lower extremity]. Sertse i sudyny - Heart and Vessels, 1, 93-96 [in Ukrainian].

7. Schreve, M.A., Minnee, R.C., Bosma, J., Leijdekkers, V.J., Idu, M.M., \& Vahl, A.C. (2014). Comparative study of venous arterialization and pedal bypass in a patient cohort with critical limb patient cohort with critical limb ischemia / M. A. Schreve, R. C. Minnee, J. Bosma [et al.] // Ann. Vasc. Surg. - 2014. - Vol. 28 (5). P. 1123-1127.

8. Inter-society for the management of peripheral arterial disease (TASC II) / L. Norgen, W. R. Hiatt, J. A. Dormandy [et al.] // Eur. J. Endovasc. Surg. - 2007. - Vol. 43 (3). - P. S1-75.

9. Пшеничний В. М. Эффективность двухуровневых инфраингвинальных реконструкций в лечении хронической критической ишемии нижних конечностей / В. М. Пшеничний, А. А. Штутин, А. А. Иваненко // Ангиология, сосуд. хир. - 2012. - № 18 (3). - С. 132-137.

10. Русин В. І. Патогенетичне обгрунтування тактики хірургічного лікування критичної ішемії нижніх кінцівок при дистальних формах атеросклерозу / В. І. Русин, В. В. Корсак, В. В. Русин // Науковий вісник Ужгородського університету. Серія : Медицина. - 2015. - № 1 (51). - С. 163-167.

11. Губка О. В. Методи лікування при атеросклеротичному ураженні стегно-підколінно-гомілкового сегмента в залежності від типу ураження / О. В. Губка, В. О. Губка, Є. В. Єрмолаєв // Клінічна флебологія. - 2012. - № 5 (1). - С. 93-94. 12. Черняк В. А. Хірургічне лікування критичної ішемії нижніх кінцівок / В. А. Черняк // Серце і судини. - 2013. - № 1. - C. 46-53.

ischemia. Ann. Vasc. Surg., 28 (5), 1123-1127. DOI: 10.1016/j. avsg.2013.08.010.

8. Norgren, L., Hiatt, W., Dormandy, J., Nehler, M., Harris, K., \& Fowkes, F. (2007). Inter-society consensus for the management of peripheral arterial disease (TASC II). Eur. J. Endovasc. Surg., 45 (1), S1-75. DOI: 10.1016/j.ejvs.2006.09.024.

9. Pshenichny, V.N., Shtutin, A.A., Ivanenko, A.A., Voropaev, V.V., Kovalchuk, O.N., \& Gaevoi, V.L. (2012). Effektivnost dvukhurovnevykh infraingvinalnykh rekonstruktsiy $\mathrm{v}$ lechenii khronicheskoy kriticheskoy ishemii nizhnikh konechnostey [Efficacy of two-level infrainguinal reconstructions in treatment of chronic critical lower limb ischa]. Angiologiya i sosudistaya khirurgiya - Angiology and Vascular Surgery, 18 (3), 132-137 [in Russian].

10. Rusyn, V.I., Korsak, V.V., \& Rusyn, V.V. (2015). Patohenetychne obhruntuvannia taktyky khirurhichnoho likuvannia krytychnoi ishemii nyzhnikh kintsivok pry dystalnykh formakh aterosklerozu [Pathogenetic substantiation of tactics of surgical treatment of critical ischemia of the lower extremities in distal forms of atherosclerosis]. Naukovyi visnyk Uzhhorodskoho universytetu. Ser. Medytsyna - Scientific Bulletin of Uzhhorod University. Series: Medicine, 1 (51), 163-167 [in Ukrainian].

11. Hubka, O.V., Hubka, V.O., \& Yermolaiev, Y.V. (2012). Metody likuvannia pry aterosklerotychnomu urazhenni stehno-pidkolinno-homilkovoho sehmenta v zalezhnosti vid typu urazhennia [Methods of treatment for atherosclerotic lesions of the femoralpopliteal segment, depending on the type of lesion]. Klinichna flebolohiia - Clinical Phlebology, 5 (1), 93-94 [in Ukrainian].

12. Chernyak, V.A. (2013). Khirurhichne likuvannia krytychnoi ishemii nyzhnikh kintsivok [Surgical treatment of critical ischemia of the lower extremities]. Sertse i sudyny - Heart and Vessels, 1, 46-53 [in Ukrainian].

Отримано 21.01.2021 
I. K. VENGER, S. Y. KOSTIV, D. V. KOVALSKYI, B. P. SELSKYY, D. V. KHVALYBOHA

I. Horbachevsky Ternopil National Medical University

\title{
SURGICAL TREATMENT OF CHRONIC LIMB ISCHEMIA IN PATIENTS WITH STENOTIC-OCCLUSIVE PROCESS OF INFRAINGUINAL ARTERIAL SEGMENT
}

The aim of the work: to improve the results of surgical treatment of chronic limb ischemia, which threatens the loss of the lower extremity, in the conditions of stenotic-occlusive process of the tibial arteries.

Materials and Methods. Surgical revascularization on the femoral-popliteal-tibial arterial chanel with stenotic-occlusive process of the tibial arteries was performed in 95 patients. Duplex ultrasound scanning and vascular contrast-enhanced computed tomography were used to determine the prevalence rate of occlusive-stenotic process of infrainguinal segment.

Results and Discussion. The main reason for the interruption of the anastomosis functioning in the remote postoperative period was thrombosis, which was diagnosed in 9 (9.68 \%) patients. Most often (3 cases) it was detected in the period of 4-5 months of the remote postoperative period. At the end of the second month, one case of thrombosis of the reconstruction segment was observed. In the middle of 9 and 10 months of the postoperative period, two cases of thrombosis were detected. And in the period between 19 and 33 months of the remote postoperative period 3 manifestations of thrombosis of the reconstruction segment were diagnosed.

After analyzing the surgical treatment of chronic limb ischemia, which threatens the loss of the lower extremity, in patients with occlusive-stenotic process of the tibial arteries, it was found that at 36 months of postoperative observation, the cumulative patency of preserved extremities was $92.63 \%$, bypass patency $-73.57 \%$. This was achieved due to a differentiated approach to the choice of the location of the distal anastomosis of the autovenous graft (distal, proximal segment of the tibial arteries) and the inclusion in the blood flow of the dorsalis pedis artery and in the vast majority of distal anastomosis type "end to end".

Key words: chronic limb ischemia; atherosclerosis; infrainguinal segment; revascularization; thrombosis; graft; anastomosis.

\author{
И. К. ВЕНГЕР, С. Я. КОСТИВ, Д. В. КОВАЛЬСКИЙ, Б. П. СЕЛЬСКИЙ, Д. В. ХВАЛИБОГА
}

Тернопольский национальный медицинский университет имени И. Я. Горбачевского МОЗ Украины

\section{ХИРУРГИЧЕСКОЕ ЛЕЧЕНИЕ ХРОНИЧЕСКОЙ ИШЕМИИ, ЧТО ЧРЕВАТО ПОТЕРЕЙ НИЖНЕЙ КОНЕЧНОСТИ, У БОЛЬНЫХ С ОККЛЮЗИОННО-СТЕНОТИЧЕСКИМ ПОРАНЕНИЕМ БЕРЦОВЫХ АРТЕРИЙ}

\begin{abstract}
Цель работы: улучшить результаты хирургического лечения хронической ишемии, что угрожает потерей нижней конечности, в условиях окклюзионно-стенотического процесса берцовых артерий.

Материалы и методы. Реваскуляризирующие операционные вмешательства на инфраингвинальном артериальном сегменте при окклюзионно-стенотическом поражении берцовых артерий проведено в 95 пациентов. С целью установления характера и распространенности окклюзионно-стенотического поражения инфраингвинального артериального сегмента применяли дуплексное ультразвуковое сканирование и компьютерную томографию с контрастированием сосудистого русла.

Результаты исследований и их обсуждение. Основной причиной прекращения функционирования анастомоза в отдаленном послеоперационном периоде был тромбоз, который диагностирован у 9 (9,68 \%) пациентов. Чаще всего (3 случая) он обнаружен в период 4-5 месяцев отдаленного послеоперационного периода. В конце второго месяца наблюдали один случай тромбоза сегмента реконструкции. На рубеже 9 и 10 месяцев послеоперационного периода обнаружили два случая тромбоза, а в период между 19 и 33 месяцем отдаленного послеоперационного периода диагностировано 3 проявления тромбоза сегмента реконструкции.

Проведя анализ хирургического лечения хронической ишемии, что угрожает потерей нижней конечности у больных с оклюзивно-стенотическим поражением берцовых артерий, установлено, что при 36 месячном послеоперационном наблюдении кумулятивная проходимость сохранившихся конечностей составила 92,63 \%, проходимость реконструкции - 73,57 \%. Подобное удалось достичь за счет дифференцированного подхода к выбору локации дистального анастомоза автовенозного шунта (дистальный, проксимальный сегмент берцовых артерий), включения в кровоток стопных артерий и формирования в большинстве случаев дистального анастомоза по типу “конец в конец”.
\end{abstract}

Ключевые слова: хроническая ишемия; атеросклероз; инфраингвинальний сегмент; реваскуляризация; тромбоз; шунт; анастомоз. 